\title{
AS TRADUÇÕES DO JESUÍTA JOSÉ DE ANCHIETA PARA O TUPI NO BRASIL COLONIAL
}

\author{
Paulo Edson Alves Filho*
}

\begin{abstract}
RESUMO: As traduções de textos religiosos e as obras de José de Anchieta (1534-1597) em tupi, destinadas à catequese, apresentavam um alto grau de inculturação e tendiam a mesclar termos católicos e indígenas. Basicamente, seus propósitos eram introduzir e difundir os preceitos do Cristianismo na cultura dos nativos do Brasil colonial. O objetivo deste artigo é demonstrar que Anchieta usou em suas traduções termos da cosmologia indígena para ilustrar conceitos cristãos sem, contudo, levar em conta seus verdadeiros significados originais. Para isso, inicialmente, analisaremos o cenário da colonização na América espanhola e portuguesa e as ações missionárias lideradas pela Companhia de Jesus. Também serão analisadas as características da língua tupi e trechos selecionados dos textos de José de Anchieta que contêm suas traduções para o tupi de importantes conceitos cristãos.
\end{abstract}

UNITERMOS: José de Anchieta; tradução jesuítica; Brasil colonial; tupi; indígenas do Brasil.

ABSTRACT: The translations of religious texts and the works of José de Anchieta (1534-1597) into Tupi, which were designed for the catechesis of the Brazilian indians, have a high level of inculturation and tend to mix Catholic and Indian terms. Their basic aims were to introduce and spread the ideas of Christianity into the culture of the natives of colonial Brazil. The aim of this article is to show that Anchieta

* Universidade de Sorocaba (UNISO). peaf@usp.br

TradTerm, 17, 2010, p. 11-30 
used in his translations terms from the Indian cosmology in order to illustrate Christian concepts, without, however, taking into account their real original meanings. Initially, Spanish and Portuguese colonization in the Americas and the missionary activities of the Company of Jesus are analyzed. The characteristics of the Tupi language are then described, and certain examples of the translations of Anchieta into Tupi which contain important Christian concepts are then analyzed.

KEYWORDS: José de Anchieta; Jesuit translations; colonial Brazil; Tupi; Brazilian indians.

\section{Introdução}

A estratégia dos primeiros franciscanos ao catequizar os astecas no início do século XVI era a de aproveitar o imaginário dos nativos e operar na lógica do outro (os astecas, neste caso) para que a conversão se tornasse uma "consequência natural", inerente a seu próprio modo de pensar (Monteiro 1995: 98).

Aparentemente, esta manobra foi bem sucedida no início da colonização do México: na primeira década da presença dos franciscanos na América Central, os missionários realizaram vários milhões de batismos entre os nativos. Contudo, sabiam que deveriam ir além do batismo e promover uma mudança cultural mais profunda. Assim, adotaram o modo indigena de vida e rapidamente tornaram-se familiarizados com os mecanismos da cultura asteca: aprenderam o náuatle (o idioma asteca) e outros idiomas secundários, para que pudessem traduzir os textos católicos e elaborar gramáticas (Ibid: 99).

A utilização da língua vernácula auxiliaria a transformar o catolicismo em uma religião dos nativos e aproximar a Europa das Américas. O êxito dos franciscanos nessa forma particular de disseminar as palavras de Deus e inseri-las nas vidas dos povos indígenas colaborou para a preservação das tradições locais e propiciou um processo de tradução na qual os índios reconheciam seus próprios deuses e entidades sobrenaturais na própria religião dos missionários.

TradTerm, 17, 2010, p. 11-30 
A construção de igrejas sobre antigos santuários assumiu um caráter de substituição, no qual não seriam esquecidos os deuses e entidades locais; o uso sistemático do idioma vernáculo não apagaria a tradição nativa à qual o Cristianismo seria sobreposto.

Desde o primeiro contato de Cristóvão Colombo com os indios da América Central, proliferaram situações nas quais as diferenças culturais vinham à tona. Colombo escrevia em seu diário de viagem que os índios estavam dispostos a trocar objetos com valores muito díspares (pedaços de vasilhas quebradas por pepitas de ouro, as quais muito agradavam os índios) (Todorov, 1999: 45). Tal passagem ilustra a percepção que o europeu tinha do nativo: eles, segundo Colombo, eram "idiotas" (Ibid: 46).

Em termos de religião, os índios eram descritos como "primitivos", pois seus rituais e convicções eram "diabólicos". Esta classificação conceitual da religião indigena era principalmente incentivada por dois elementos: (a) o imaginário judaico-cristão que assim classificava a adoração "pagã" durante a Idade Média na Europa e (b) o fato da cultura indigena incorporar o canibalismo e a adoração de elementos de natureza, como por exemplo, o trovão. Traduzidos no código religioso europeu, tais costumes - similares a algumas seitas pagãs da Europa - eram comparados a uma ligação com o demônio.

Esta tendência em relacionar o "novo" com o "velho" era também notada no modo como os ameríndios viam os europeus. O deus asteca Quetzalcoatl, branco e barbudo, havia vindo e retornado ao leste. Também no leste, encontrava-se a morada de outro deus inca, branco e barbudo, Viracocha (Galeano, 1976: 29). Por analogia, com a chegada das primeiras caravelas, os indios projetavam suas entidades religiosas nos homens brancos.

Provenientes de uma terra distante, trazendo consigo estranhos poderes e úteis objetos, os indios tupis associavam os europeus a xamãs tribais, que vagavam de aldeia em aldeia curando, prevendo o futuro e profetizando sobre o paraíso. Em pouco tempo, os jesuítas se apropriariam de seus discursos para que a pregação tivesse o mesmo efeito sobre os homens da terra. A própria palavra "caraíba", que originalmente significava ho- 
mem com poderes, deixaria de designar os pajés para tornar-se o termo utilizado para definir os conquistadores portugueses em geral. No contexto deste deslocamento de significados - a "aventura semântica", na expressão de Meliá -, pode-se entender melhor o lugar ocupado pelos europeus na cosmologia indígena (Fausto, 1992: 386).

Eric Cheyfitz (apud Robinson, 1997: 64) afirma que os europeus percebiam que faltava tudo às pessoas do Mundo Novo: símbolos, vestimenta, propriedade, tecnologia e até mesmo uma lingua (já que os europeus consideravam o idioma nativo como um mero "tagarelar"). Esta radical diferença cultural e linguística exigia do homem branco repensar significativamente sua visão de mundo e de como lidar com este encontro inusitado: "O que ou quem são os 'selvagens'? De onde vieram? Deveriam ou poderiam ser transformados em europeus?”

A Igreja Católica - particularmente a Companhia de Jesus, à qual Anchieta pertencia - tinha planos para lidar com os "selvagens" do Brasil colonial. Se os africanos não suscitavam as mesmas indagações politicas e sociais que os índios, a América e seus nativos inocentes chamavam a atenção dos europeus quanto à possivel expansão da nação cristã; eram diferentes dos povos africanos que, segundo o imaginário europeu contemporâneo, tinham sido concebidos como descendentes de Ham e amaldiçoadas por Deus com a escravidão eterna.

A Espanha tinha a tarefa dupla da conquista territorial e espiritual das novas terras, o que resultaria em disputa entre Igreja e colonizadores. A Igreja e a Coroa deviam defender a fé e os princípios que regiam o mundo e difundir a mensagem cristã entre os "bárbaros". A Igreja, sempre ativa no processo colonizador, tentou persuadir a Coroa e os colonizadores a desenvolverem suas atividades na América de forma mais humana - o que nem sempre ocorria.

Quem eram os índios sul-americanos e como os europeus deviam tratá-los foi assunto amplamente discutido no século XVI por teólogos como Juan Ginés Sepulveda, Bartolomé de las Casas e Francisco de Vitória. Todos os três espanhóis, apesar de terem visões diferentes sobre os nativos americanos, concordavam em um ponto: os nativos deviam aceitar a regra dos espa-

TradTerm, 17, 2010, p. 11-30 
nhóis, pois estes, além de julgarem-se mentalmente superiores, tinham leis - divinas e naturais - que lhes delegavam o direito de conquistar e escravizar os nativos da América. Era consenso entre os espanhóis que a adoração de ídolos por parte dos nativos era totalmente relacionada à demonolatria. Poucos concordavam com Las Casas quando ele afirmava que "essas idolatrias refletiam uma sincera expressão religiosa" (apud Vainfas, 1995: 27).

A "conquista" espiritual na América Espanhola, particularmente no Peru e no México, foi levada a cabo de maneira firme e clara: autoridades seculares, padres e missionários viam idolatria nas religiões dos índios e a tratavam como crime passível até mesmo de pena de morte.

O explorador espanhol Hernán Cortés considerava vital que os índios não só se sujeitassem ao trono espanhol, mas também aos mistérios de Cristo. A Coroa Espanhola julgava-se no direito de declarar guerra aos indivíduos que rejeitassem o Evangelho. Antes de atacar qualquer nativo, os espanhóis eram obrigados a ler o Requerimiento, declaração que lhes oferecia a chance de aceitar Cristo e o império. Caso não concordassem, seriam aniquilados. Era intrigante o fato de o documento - que ofertava aos índios a escolha entre aceitar uma religião e governo desconhecidos ou a morte - ser lido solenemente em espanhol. A tradução, ou a falta dela, era decisiva em não transmitir a mensagem aos nativos. Caso escolhessem não submeter-se a Deus, a violência era permitida, mesmo que os ouvintes não entendessem o que lhes era dito. Através do Requerimiento, batalha, subjugação, escravização, morte e roubo eram culpa dos índios, não dos espanhóis, uma vez que os primeiros tinham a permissão de "escolha".

\section{Os Jesuitas no Brasil e os colonizadores portugueses}

Diferentemente das experiências dos espanhóis com os maias no México e os astecas no Peru, os colonizadores portugueses não encontraram nenhum sinal de paganismo por meio de ídolos ou máscaras nas terras que viriam a ser o Brasil. Os jesuitas portugueses e colonizadores geralmente observavam os 
silvícolas como ateus, como "pessoas que não tinham nenhum conhecimento de Deus ou ídolos; nada adoram, não conheciam Deus; só chamavam o trovão de Tupã, que significava coisa divina." (Vainfas, 1995: 26)

O jesuíta Manuel da Nóbrega via os índios brasileiros como um "papel em branco" no qual qualquer coisa poderia ser escrita.

A Companhia de Jesus muito usou as estratégias que os franciscanos usaram nas primeiras conversões no México. Apostavam na convergência cultural ou inculturação, unindo o catolicismo a elementos indígenas, por meio da tradução e da equivalência. Além disso, o próprio ritual cristão, com sua pompa e música, atraía os nativos e proporcionava uma conversão mais branda.

Os rituais dos índios brasileiros foram extensamente registrados em relatos de viajantes europeus pelo Brasil. Um dos primeiros, escrito por Nóbrega, é contraditório, pois primeiramente, afirmava que os tupis não tinham religião e posteriormente informava que ocasionalmente feiticeiros apareciam nas tribos e os índios os saudavam com danças e banquetes. Estes feiticeiros portavam uma vara com uma cabaça na ponta, instrumento mágico com a qual dialogavam e depois transmitiam previsões e conselhos. O relato do padre francês André Thevet, descrevia estes feiticeiros como pessoas com vidas ruins que se dedicam ao diabo.

Outra crônica, escrita por Hans Staden, náufrago alemão capturado pelos tupinambás, relatava que as cerimônias indigenas eram tola superstição e Jean de Lery detalhava pormenores desses mesmos rituais.

As quatro descrições, apesar de pequenas diferenças, ofereciam uma imagem quase homogênea de como as cerimônias, danças e rituais eram importantes e ligadas ao sobrenatural na cultura tupi.

Os testemunhos dos frades Simão de Vasconcelos, Yves d’Evreux e Manuel da Nóbrega dão a ideia de que a ação missionária seria tarefa em prol da evolução humana. Segundo eles, os europeus e ameríndios descendiam do mesmo núcleo e ambos tinham as sementes do cristianismo, a verdadeira reli- 
gião. Seriam padres e missionários os responsáveis por guiar os nativos da "tribo perdida" à mesma fase evolutiva dos europeus cristãos. A conversão, por meio do conhecimento das Sagradas Escritas e do aprimoramento da fé, lhes traria a pureza e a virtude perdidas depois que Adão comeu a fruta proibida.

Para o frade Yves d’Evreux, os tupis até mesmo já conheciam Deus: ele era Tupã, ou seja, o trovão. De acordo com d'Evreux, a religião natural havia deixado vestígios em seus corações. Contudo, não conheciam a essência nem a Trindade; só poderiam conhecê-las após a conversão à fé cristã.

Era neste contexto peculiar que a missão catequética dos Jesuitas operaria a "tradução" cultural a partir de 1549. Os homens da Companhia de Jesus tinham a tarefa de disseminar o Cristianismo entre os nativos, cujas características culturais os europeus pouco conheciam.

As atividades jesuíticas no Brasil, apoiadas pela Coroa Portuguesa, duraram 200 anos. A missão dos jesuitas tinha raízes nas descobertas marítimas portuguesas que promoveram a expansão da fé a todos os povos pagãos. Para operacionalizar os ensejos da Igreja Católica em sua colônia, Portugal criou o Conselho Ultramarino e a Mesa da Consciência e Ordem, órgãos que coordenavam as expedições missionárias. A Coroa Portuguesa organizava e patrocinava as expedições de evangelização, a construção de igrejas e até mesmo promovia a criação de aldeamentos, nos quais convergiam jesuitas e indígenas. Desse modo, a Igreja estava a serviço do Império português e monitorava os objetivos da conquista e colonização.

A Igreja no Brasil Colonial seguia também as diretrizes do Conselho de Trento quanto às normas missionárias e aos principais elementos a serem transmitidos aos nativos. Por meio do Padroado, a Coroa dava apoio à Igreja para que os indígenas fossem protegidos de violências cometidas pelos colonizadores. Os jesuitas organizavam a resistência de índios contra a escravidão e a matança promovidas pelos colonizadores, em especial, no sul do Brasil.

Contudo, a partir da metade do século XVII, os jesuitas se tornaram cada vez mais independentes do governo português. Foi a partir de 1756 , com a política expansionista portuguesa 
sob a administração do Marquês de Pombal, que os colonizadores foram estimulados a desmantelar o controle dos jesuitas sobre a população indígena. Pombal, que gradualmente reduziu o poder dos homens da Companhia de Jesus em Portugal e nas colônias, se dispôs contra os jesuítas, acusando-os de estarem agindo contra os interesses da Coroa. Em 1759 expulsou a Companhia de Jesus da metrópole, fechou todas as faculdades e missões, confiscou suas propriedades e prendeu vários padres. O governante alegava que os jesuitas resistiam a abandonar as missões - ordem decretada pelo Tratado de Madri assinado por Portugal e Espanha em 1750 - e que os missionários encorajavam os índios a resistirem às determinações dos países colonizadores.

Além de expulsar a Companhia de Jesus do Brasil, Pombal determinou a proibição da língua tupi em estabelecimentos educacionais. Desde então, o português tem sido o idioma ensinado nas escolas e língua oficial do país por decisão da primeira Assembleia Constituinte de 1823.

\section{A lingua tupi}

Estima-se que existiam entre dois a quatro milhões de índios no Brasil em meados do século XVI. Grosso modo, os guaranis habitavam desde o sul do atual estado de São Paulo até o Rio Grande do Sul. Os tupinambás viviam ao longo do litoral de São Paulo até o leste do estado do Maranhão. Todos eram falantes de línguas pertencentes à família linguística tupiguarani, a qual incluía um total de 39 idiomas indígenas.

O tupi, ou tupinambá, era a principal língua falada à época e utilizada pelos jesuítas e pela administração colonial. Embora os alunos nas escolas jesuíticas fossem ensinados a ler e escrever em português e latim, a língua utilizada na instrução era o tupi, também conhecida como lingua geral ou o grego da terra. Os jesuítas em suas missões catequéticas o utilizavam para disseminar os dogmas cristãos. Não é difícil imaginar que o Brasil poderia ter se tornado um país genuinamente bilíngue, a exemplo do Paraguai, onde toda a população fala guarani e espanhol.

TradTerm, 17, 2010, p. 11-30 
Como herança da língua vernácula da época, temos, principalmente, nomes de cidades e regiões. Por exemplo, "Sorocaba" e "Jundiai" (respectivamente, "terra fendida" e "rio do bagre") foram assim nomeadas devido às suas características geográficas. Além disso, palavras tupi são encontradas na culinária, na fauna e em um grande número de expressões cotidianas do português do Brasil.

O tupi tem caracteristicas peculiares: (a) era originalmente um idioma ágrafo; (b) não apresenta inflexões, artigos definidos, indefinidos nem gêneros gramaticais; (c) os substantivos e adjetivos são os mesmos no plural e no singular; e (d) tem escassos substantivos abstratos para indicar qualidade ou semelhança, tais como "injustiça", "bondade", "cor", "beleza", "distância", "tamanho" etc.

\section{Anchieta e o papel do missionário católico}

De acordo com Grandville (1979), o papel do padre católico foi redefinido pelos índios. Eles não o viam a serviço de Deus, mas sim como alguém com uma importante posição na sociedade tribal. O missionário vinha de uma terra messiânica, do alémmar e tinha poderes para falar a favor dos índios sempre que necessário. As instruções dadas pelos jesuitas conferiam a eles a posição de médicos na cura da alma. Na função de catequizadores, os padres substituiam os xamãs e se tornavam os novos curandeiros dos índios (Pompa, 2003: 67-69), com suas doenças e remédios trazidos da Europa.

O jesuita tinha força para exigir, falar e tomar decisões junto às autoridades em nome de toda a comunidade, pois era o portador de esperança messiânica. Suas mensagens eram sobre uma terra melhor, mais segura e mais moderada, livre das coisas ruins que torturavam os nativos.

Anchieta, assim como todos os jesuitas, promoveu a inculturação do catolicismo em solo brasileiro para propiciar certa tolerância aos rituais - chamadas pelos jesuítas de "jogos" - da gente da terra (Pompa, 2003: 68).

Para promover a difusão da mensagem católica e assim encorajar a aculturação dos índios, Anchieta criou um extenso 
corpus, constituído principalmente de poemas e peças teatrais escritas em português, espanhol e tupi. Criou um novo teatro, que não seguia estritamente nem os rituais (jogos) indigenas, nem os parâmetros do teatro europeu. Suas peças não eram destinadas necessariamente a ensinar religião, mas sim a promover os aspectos básicos de preceitos cristãos (Anchieta, 1977: 44).

Anchieta se aproveitou de um grande número de elementos pagãos e cristãos nos seus enredos, encenados por índios e colonos. Suas peças fundiam o natural e o sobrenatural, realismo e simbolismo, dança e música, apesar da aparente incompatibilidade entre os hábitos, valores e tradições dos silvícolas e os valores morais e espirituais da Igreja (Ibid: 46). Anchieta era estudioso do tupi e sua Gramática Tupi foi publicada em 1595 em Coimbra. Também escreveu sermões, confessionários e orações aos santos. Entre suas peças de destaque encontram-se "Na Festa de Natal", "Na Aldeia de Guaraparim", e "Na Festa de São Lourenço" (Ibid: 46), visivelmente inspiradas na forma, métrica e nos personagens (anjos e demônios) das obras de Gil Vicente.

Anchieta adaptou o conteúdo de seu trabalho ao ambiente indígena e assim criou um conjunto peculiar de obras, destinado ao público de um Brasil recém-colonizado. Suas peças continham palavras e rimas em tupi; contudo, o ritmo e os ciclos eram portugueses:

Jandé, rubeté, Iesu,

Jandé rekobé meengára

Oimomboreausukatú

Amotareymbára de Jandé. (Anchieta, 1954: 559)

(Jesus, nosso verdadeiro Pai

O Deus de nossa existência derrotou nosso inimigo)

O familiar e o exógeno fundiam-se e este processo era apenas parte de uma estrutura mais complexa que tinha a finalidade de transmitir a mensagem inculturada aos índios. 


\section{Estratégias para a realização da tradução cultural}

Uma das práticas jesuíticas era a tradução cultural no sentido de tentar transmitir, de uma cultura a outra, uma gama de conceitos sem equivalentes na cultura de chegada. Os resultados eram frequentemente imprevisiveis. Alfredo Bosi (1992: 65) afirma:

Na passagem de uma esfera simbólica para outra Anchieta encontrou óbices por vezes incontornáveis. Como dizer aos tupis, por exemplo, a palavra pecado se eles careciam até mesmo da sua noção, ao menos no registro que esta assumira ao longo da Idade Média européia?

A estratégia que Anchieta escolheu para transmitir o cristianismo frequentemente era a de procurar algum elemento correspondente entre os idiomas português e tupi. Contudo, os resultados eram desiguais (Ibid: 67), como a tradução da palavra "anjo" por "karaibebe". Este neologismo derivava de "karai" (o profeta índio) e "bebé" (alado). Nesse sentido, o conceito era estranho ao índio e ao europeu: um profeta voador não era familiar ao nativo nem ilustrava adequadamente a figura de um anjo, segundo a definição bíblica.

Ao tentar incutir a ideia de Céu e Inferno, os europeus projetavam seu próprio imaginário sobre o dos silvícolas: viam os índios como sua sombra, pois "traziam o próprio Lúcifer no porão dos navios" (Vainfas 1995: 25). Em termos etnológicos, os colonizadores não atentavam à alteridade. O conceito de "demônio" era estranho aos maias, aos astecas e aos tupis. As divindades do nativo eram caracteristicamente neutras, nem boas nem ruins, muito diferentes dos elementos sobrenaturais cristãos. Suas características não se encaixavam no conceito dialetal europeu de universo, no qual forças opostas eram vistas como recíprocas e complementares. As entidades dos silvícolas tinham poderes extraordinários e destrutivos, mas não se relacionavam exatamente a algo "diabólico", conforme a cosmologia cristã.

Todavia, Anchieta tentou ajustá-las aos parâmetros religiosos europeus. A inculturação promovida por Anchieta permaneceu em um nivel meramente superficial e os próprios ele-

TradTerm, 17, 2010, p. 11-30 
mentos sobrenaturais indigenas foram também reinterpretados por meio de atributos cristãos.

O Deus dos portugueses foi chamado de "Tupã" na conversão / tradução realizada pelos jesuítas. A partir da atividade missionária, Tupã assumiu uma nova condição: era o deus supremo, tinha uma mãe ("Tupansy", a Virgem Maria), que também era sua filha, tinha uma casa e um reino (Bosi, 1992: 67).

Para que a perspectiva religiosa europeia fosse inserida na cosmologia indígena, Tupã carecia de uma força oposta que representasse as trevas. Para tal, Anchieta escolheu "Anhanga" como o conceito de diabo. "Anhanga", no imaginário indigena, era o protetor da selva e dos animais e tinha poderes e habilidades surpreendentes, capaz de trocar de forma e atormentar os seres humanos. Neste novo padrão mitológico, Anhanga assumiu o papel do príncipe das trevas e era diretamente responsável por todos os maus hábitos do ameríndio, tais como o canibalismo, a poligamia e a embriaguez por cauim. Pode-se aventar que Anchieta tenha feito essa escolha menos pela essência diabólica de Anhanga e mais pelo medo que esta entidade proporcionava aos homens da terra.

Bosi observa que o método mais eficiente de destruir os maus hábitos dos índios havia sido descoberto depressa: generalizando o pavor entre os nativos e estendendo-o a todas as entidades que se manifestavam nos transes e cerimônias (Ibid: 69).

Se na Europa os rituais pagãos e a adoração de ídolos eram condenados e suprimidos, na América os europeus teriam o mesmo dever de exterminá-los (Mello e Souza: 1993). Assim, justifica-se o fato de Anchieta ter escolhido o diabo como o personagem mais presente e atuante em seus autos. Por meio da interlocução do demônio, Anchieta conceituava os rituais e o comportamento dos tupis como diabólicos, circunscrevendo-os e condenando-os.

O canibalismo e a poligamia eram elementos fundamentais para a vida social dos índios e causavam grande repugnância aos missionários. Embora os índios não os relacionassem a Anhanga, o canibalismo era resultado da guerra e importante para a supremacia da tribo sobre seus inimigos. O prisioneiro de guerra mantido cativo por vários meses era bem tratado e até

TradTerm, 17, 2010, p. 11-30 
mesmo recebia uma esposa na tribo inimiga. Em tempo determinado, era morto e seus despojos eram consumidos em um banquete. Seu sangue era ingerido pelas velhas e utilizado pelas mães, que o espalhavam sobre seus peitos. Se o prisioneiro tivesse adquirido uma esposa durante o cativeiro, ela lamentava sua morte e também participava do banquete. Seu algoz era proibido de festejar e ficava recluso em prol de sua proteção e da aldeia. O ritual de canibalismo justificava-se por duas razões: vingança e incorporação da alma corajosa do inimigo à alma do executor.

A poligamia era prática útil e significativa na vida tribal diária: enquanto uma mulher trabalhava no campo, a outra (ou as outras) cuidava das crianças e dos afazeres na aldeia.

Manipulando e traduzindo estes elementos, Anchieta reorganizou seus significados no imaginário tupi. Tupã, com seus poderes divinos de um lado, Anhanga e os costumes bárbaros, como poligamia e canibalismo, de outro. A tarefa dificil e incerta dos jesuitas de estabelecer e traduzir novas definições era agravada por se tratar de duas culturas e dois idiomas muito diferentes.

Navarro (2001) explicita um conjunto de palavras e expressões traduzidas por Anchieta sem equivalência conceitual exata para transmitir o dogma católico. Além de "karaí-bebe", mencionado anteriormente, imprecisa era a tradução feita por Anchieta da palavra "pecado". Em seus textos, ela figura como "tekó-aíba", "tekó-angaipaba" ou "tekó-poxy" (vida ruim ou cultura ruim das pessoas) ou por vezes é mantida em português. Quaisquer que fossem utilizadas, faziam pouco sentido ao nativo. Com efeito, o conceito de pecado carecia de uma ordem maior de definições. Pecado - uma transgressão do testamento conhecido de Deus ou qualquer princípio ou lei cristã - não teria exatamente a definição de vida ruim pelos costumes indígenas, mas sim pelos costumes europeus. Assim, a palavra "pecado" precedia de uma definição de Deus e do que seria uma "vida ruim".

Além de "pecado", Navarro (2001) arrola as expressões "ratá" (o "fogo" de Anhanga, relacionado a "inferno", um local de sofrimento eterno, um conceito totalmente estranho para o nativo) e "moro-potar-e'yma" (literalmente, não desejar sensualmente 
as pessoas) utilizada para designar "pureza". É evidente que a escolha tradutória de Anchieta pela expressão "moro-potar-éyma" era carregada de ideologia, que neste caso, condenava o comportamento sexual dos índios que seguiam os princípios católicos.

Vicente Rafael aponta em seu estudo (1988: 20-21) sobre as traduções da doutrina cristã para o idioma tagalo, feita por missionários nas Filipinas, características semelhantes às encontradas nas traduções de Anchieta. Os jesuitas que lá atuaram também mantinham "palavras intraduziveis" em espanhol no discurso tagalo. Geralmente eram palavras que tinham importante significado na perspectiva religiosa, tais como "domingo", "Virgem Maria", "Santa Igreja", "tentação" e "reino". Elas não eram traduzidas e pontuavam o fluxo do discurso cristão no idioma local.

Nos trechos da oração "Pai Nosso" e nos Dez Mandamentos traduzidos por Anchieta, encontramos as mesmas palavras mantidas em português:

\author{
"Eimoeté Domingo" (Anchieta 1992: 143) \\ (Guardar o domingo) \\ Orê rûb Ybàkupe tekóar,Ymoete pyramo,nde rera toikó nde \\ de T’our Reino (Navarro 2001: 62) \\ (Pai nosso que estás no céu, santificado seja vosso nome. \\ Santificado seja o vosso nome. Venha a nós o vosso reino) \\ Ore moar ukar ume iepe Tentação pupé (Ibid.: 63) \\ (não nos deixe cair em tentação)
}

Segundo Rafael, a manutenção de algumas palavras na língua do colonizador explicitava a inadequação da língua vernácula para expressar a verdade de Deus. Para contornar esta "falha", o próprio tupi - no caso do Brasil Colonial - precisou ser reformulado e incorporar um vocabulário exógeno ao idioma estrangeiro, considerado pelo colonizador como superior e mais adequado para expressar os preceitos de Deus.

A partir dessa cadeia de tradução, Rafael (Robinson, 1997: 85) desenha a hierarquia emergente das linguas: a palavra de Deus era expressa adequadamente em latim. O espanhol, idioma do Império, encontrava-se em um nivel inferior, assim como 
o português no Brasil Colonial. Em um nível abaixo deste último, encontravam-se o tagalo e o tupi. Rafael conclui que "quanto mais distante de Deus um idioma e sua cultura encontravamse, menos adequados a participarem da 'economia divina', ou seja, a troca de orações e respostas, presentes e gratidão entre Deus e crentes" (Robinson, 1997: 86).

Em decorrência da hierarquia proposta por Rafael, neologismos surgiram, como, por exemplo, "tupãoka" (casa de Tupã, igreja), acompanhados do esforço dos jesuitas em disseminar o catolicismo. Agregando a palavra "Tupã" a "sy" (Tupãsy), Anchieta acreditava ter descrito uma imagem clara da mãe de Jesus. Contudo, em outras referências à mãe de Deus, não traduziu o termo "virgem" para o tupi:

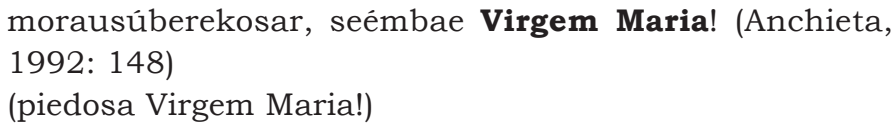

A opinião de Rafael quanto à inferioridade e insuficiência do idioma do colonizado para assuntos religiosos é reforçada pela estratégia de Anchieta de manter palavras chaves em português. Os trechos selecionados da oração "Ave Maria" demonstram sua escolha:

Ave Maria, graça tynysémbae resé, (Ave Maria, cheia de graça)

(...)

Santa Maria Tupãsy, (Anchieta, 1992: 148)

(Santa Maria, mãe de Deus,)

Em outros casos, Anchieta criava palavras que mesclavam português e tupi:

Arobiar Túbamo sekó

(Acreditamos em Deus Pai)

Arobiar Tayramo sekó

(Acreditamos em Deus Filho)

Arobiar Espirito Sántoramo sekó (Anchieta, 1992: 149)

(Acreditamos no Espírito Santo)

TradTerm, 17, 2010, p. 11-30 
Acrescentando o sufixo tupi "ramo", que significa "condição de" à expressão em português "Espírito Santo", aparentemente Anchieta enfatizava a condição desta entidade sobrenatural e assim a tornava mais familiar a público. Tal recurso em muito se assemelhava às diretrizes do papa Gregório dadas aos missionários incumbidos de converter os pagãos na Inglaterra do século VIII. Suas instruções determinavam que elementos pagãos não deviam ser descartados e deviam ser adequados aos preceitos cristãos o máximo possível, pois acreditava que seria impossivel extirpá-los de todo das almas consideradas "ásperas" e "bárbaras" (Brandão, 1978: 14).

Anchieta, seguindo esta mesma premissa, não só manipulava a língua vernácula como também era criativo quanto à tradução cultural. Em termos etnográficos, esta tradução cultural equivalia ao processo que consolidava uma grande variedade de discursos ou mensagens culturais em um determinado texto e, de certo modo, não tinham nenhuma fonte definida e única.

Na peça "Recebimento do Padre Marçal Beliarte" (1589), nota-se que Anchieta usou vários "textos" fonte para produzir o texto "traduzido". A peça, como também a maioria das outras que escreveu, apresenta vários demônios e "Tupansy" em uma luta entre o Bem e o Mal. Seu estilo, enredo e caráter eram baseados nos trabalhos de Gil Vicente, nos quais o Bem sempre triunfa. Os diálogos dos personagens estão em português e tupi. Anchieta introduziu nesta representação um importante elemento do código de conduta indígena e habilmente o distorce em relação ao significado original.

Um dos demônios (Makaxera) é assassinado no ritual tradicional de canibalismo por um índio corajoso, sob as ordens de "Tupansy" (mãe de Deus). Pouco antes de matá-lo, o índio Añangupiara diz:

Kueseñey, Tupansy (Como antes, a Mãe de Jesus) Nde Reytyki, nde peabó (o arruinou e o esmagou) Aé xe mboú korí (assim ela me enviou aqui)

Ko aikó nde akánga kábo (para partir sua cabeça)

Nei! Ejemosakói (defenda-se, besta feroz)

Tajopune, marandoéra (eu o ferirei, falsário) 
(O índio arrebenta a cabeça do demônio)

Te! Ajuká Makaxera (Pronto! Matei Makaxera)

Omanongatú Moxy (O Mal não existe mais...)

'Añagupiara' xe rerá! (Sou Añagupiara!) (Anchieta 1977:

245)

Por meio de cenas violentas, comuns em suas peças, Anchieta reforçava a mensagem cristã. Se o ritual de sacrificio de um cativo servia para nutrir as virtudes dos guerreiros, nos textos do jesuita este mesmo sacrificio tem o intuito de afastar o mal. Em sua tradução ou reescrita, Anchieta não considerava o ritual como um processo de incorporação, mas sim de extirpação. Robinson (1997: 93) afirma que "as palavras do povo colonizado podem ser 'citadas', 'traduzidas', 'relidas' e 'reescritas' pelos colonizadores de modo a remodelar a cultura colonizada de acordo com os interesses da dominação".

Na peça "Na Aldeia de Guaraparim", Anhanga fala a favor dos costumes indígenas, condenados pela Igreja. Anchieta reorganizou um conjunto de elementos cotidianos dos silvícolas visando obter espaço para inserir o dogma cristão. Assim fala o demônio:

Iemoyrõ, morapiti

(Vocês tornam-se furioso e mata as pessoas)

Io'u, tapuia rara

(Vocês comem um ao outro, vocês aprisionam índios inimigos)

Aguasá, moropotara

(vocês têm concubinas, entregam-se ao desejo sensual)

Manhana, syguaraiy:

(vocês espiam, se prostituem)

Naipotari abá seiara (in Navarro 2001: 65)

(eu não quero que ninguém deixe de fazer tais coisas)

Anchieta mesclava o teatro ibérico, preceitos católicos e rituais indigenas em seus escritos. Todos esses elementos, traduzidos de forma a favorecer seus propósitos missionários, apresentavam um alto grau de catolicismo inculturado e serviam à aculturação dos índios.

TradTerm, 17, 2010, p. 11-30 
Adone Agolin (apud Pompa 2003: 92-93) sintetiza as técnicas de composição de Anchieta: (a) introdução de português ou palavras latinas, (b) inserção de neologismos formados a partir de palavras em português ou latim agregadas a sufixos tupi, (c) escolha de um único significado a partir de palavras com vários significados em tupi, e (d) construções sintáticas que exprimiam conceitos quando não era possivel encontrar uma solução satisfatória na língua vernácula.

\section{Considerações finais}

Anchieta escolheu usar palavras e expressões em tupi, como "Tupã", "Anhangá" ou "karaibebé", para transmitir a mensagem cristã em textos inculturados que uniam mitologia cristã e indigena. Contudo, em uma análise mais detalhada, tal estratégia trazia resultados superficiais, pois os significados e valores originais eram drasticamente alterados no contexto colonial e religioso. Os jesuítas os mantinham como elementos familiares em seus discursos, mas o significado destes elementos era completamente modificado por meio da ideologia catequética, visando à aculturação dos indígenas. Tais reformulações acarretavam novos valores ao que era escrito pelos missionários. Essas mesmas reformulações linguísticas eram, por vezes, acompanhadas de expressões emprestadas do português, tais como "Santa Cruz" e "pecado", que designavam conceitos alheios aos indígenas até então.

Acreditamos que a estratégia utilizada por Anchieta tem muito em comum com o conceito de equivalência dinâmica proposta por Eugene Nida (1964), uma vez que são percebidas adaptações de conceitos católicos para o mundo tupi para promoverem a catequização do indígena. Aventamos a hipótese de que, havendo a necessidade da conversão do gentio, tais adaptações tornam-se significativas, conforme Nida propõe aos tradutores missionários.

Contudo, ao manipular elementos da mitologia tupi e ao inserir novos elementos abstratos em seus textos, Anchieta acabou por criar uma terceira esfera religiosa, situada entre a cosmologia cristã e pagã. Foi por meio de sua estratégia de tra-

TradTerm, 17, 2010, p. 11-30 
dução que o jesuita antecipou em quase quatro séculos as diretrizes do Vaticano de 1969, Comme le prévoit, a qual sancionou a adaptação e a inculturação de textos litúrgicos pelos tradutores para se adequarem melhor ao público receptor.

\section{Referências Bibliográficas}

ANCHIETA, José S. J. (1954) Poesias. Manuscrito do século XVI, em português, castelhano, latim e tupi. Tradução de Maria de Lourdes de Paula Martins. São Paulo: Comissão do IV Centenário. José S. J. (1977) Teatro de Anchieta, ed. Armando Cardoso. São Paulo: Loyola, 1977. José S. J. (1992) Doutrina Cristã Tomo I: Catecismo Brasílico São Paulo: Loyola, 1992.

BEALL, Stephen, M. (1996) "Translation and Inculturation in the Catholic Church". In: Adoremus Bulletin, Online Edition - vol. II, n. 6, October 1996.

BOSI, Alfredo (1992) Dialética da Colonização. São Paulo: Companhia das Letras.

BRANDÃO, Helena H. N. (1978) Uma Análise do Discurso Catequético de Anchieta. Dissertação de Mestrado, FFLCH-USP. São Paulo.

CARDOSO, Armando. (1992) "Pe. Joseph de Anchieta, S. J.”. In: CUNHA, Manoela C. (ed.). História dos Índios no Brasil. São Paulo: Companhia das Letras.

FAUSTO, Carlos. (1992) "Fragmentos de História e Cultura Tupinambá". In: CUNHA, Manoela C. (ed.). História dos Índios no Brasil. São Paulo: Companhia das Letras.

GALEANO, Eduardo (1976) As Veias Abertas da América Latina. Rio de Janeiro: Editora Paz e Terra.

GRANVILlE, Maria Antonia (1979) Ação Catequética do Padre Anchieta Observada a Partir de Algumas de Suas Composições Teatrais. Dissertação de Mestrado, FFLCH-USP. São Paulo.

HOORNAERT, Eduardo (1982) A Igreja no Brasil Colônia. São Paulo: Ed. Brasiliense.

MELLO E SOUZA, Laura de (1993) Inferno Atlântico: demonologia e colonização. São Paulo: Companhia das Letras.

MONTEIRO, Paula (1995) Entre o Mito e a História. Petrópolis: Vozes.

TradTerm, 17, 2010, p. 11-30 
NAVARRO, Eduardo de Almeida (2001) "The Translations of the First Texts to Tupi, the Classical Indian Language in Brazil”. In Crop, no. 6, 51-73. São Paulo, Humanitas.

PAGDEN, Anthony (1999) The Fall of the Natural Man. Cambridge: Cambridge University Press.

PAIVA, José Maria (1982) Colonização e Catequese. São Paulo: Autores Associados.

POMPA, Cristina (2003) Religião com Tradução: Missionários, Tupi e Tapuia no Brasil Colonial. Bauru: EDUSC.

RAFAEL, Vicente L (1988) Contracting Colonialism, Translation and Christian Conversion in Tagalog Society Under Early Spanish Rule. Ithaca: Cornell University Press.

ROBINSON, Douglas (1997) Translation and Empire: Postcolonial Theories Explained. Manchester: St. Jerome.

TODOROV, Tzvetan (1999) A conquista da América: A Questão do Outro. São Paulo: Martins Fontes.

TYMOCZKO, Maria (1999) Translation in a Postcolonial Context. Manchester: St. Jerome.

VAINFAS, Ronaldo (1995) A Heresia dos Índios. São Paulo: Companhia das Letras. 